\title{
ELECTING JUSTICE ROUSH TO THE SUPREME COURT OF VIRGINIA
}

Carl Tobias:

\begin{abstract}
In late April 2015, the Supreme Court of Virginia announced that Justice LeRoy F. Millette, Jr. would retire on July 31, 2015. Democratic Governor Terry McAuliffe expeditiously created an open process for tapping a worthy successor. At July's conclusion, the Governor appointed Fairfax County Circuit Judge Jane Marum Roush, an experienced, consensus jurist. On a Sunday night, merely two days after Roush swore her oath of office, Republican General Assembly leaders proclaimed their caucuses' intention to elect another individual, despite conceding that Roush was very qualified. During the August special session, this concerted GOP endeavor prompted a Republican senator to join Democrats who opposed the prospect and concomitantly adjourned. GOP leaders then contended that legislators remained in session, as the Virginia Constitution explicitly prescribes Senate and House of Delegates consent to adjourn. The Governor's Counsel next penned an opinion that concluded that lawmakers had adjourned, so McAuliffe could appoint Justice Roush to the Court again, a choice that he implemented thirty days after adjournment. Because these efforts precipitated a constitutional standoff and will consequently plague future judicial selection, they warrant analysis.

The initial part of this Article chronicles the rise and evolution of Virginia court selection. Part Two scrutinizes recent machinations, determining that the procedures now merit improvement. The last section proffers suggestions. For the near term, the Assembly ought to promptly elect Roush. She brings

* Williams Chair in Law, University of Richmond. Thanks to Peggy Sanner and Katie Lehnen for fine ideas, Leslee Stone for fine processing, as well as Russell Williams and the Hunton Williams Summer Endowment Fund for generous, continuing support. Remaining errors are mine.
\end{abstract}


twenty-two years of judicial service, including over five months as a justice. Moreover, Roush's removal for reasons unrelated to her abilities, earlier performance, or future capacity to serve would make a mockery of the selection regime, undermining citizen respect for it, the whole state judiciary, as well as the Governor and the Assembly. Across the longer term, the Commonwealth must evaluate and initiate changes that will enhance selection.

\section{Table of Contents}

I. Introduction 361

II. A Brief History of Virginia Judicial Selection. 362

III. Justice Roush's Appointment.... 364

IV. Suggestions for the Future 372

A. Short-Term Suggestions.

B. Longer-Term Suggestions 373

V. Conclusion 374

\section{Introduction}

In late April 2015, the Supreme Court of Virginia announced that Justice LeRoy F. Millette, Jr. would retire on July 31, 2015. Democratic Governor Terry McAuliffe expeditiously created an open process for tapping a worthy successor because the court needs all of its colleagues to work productively. At July's conclusion, the Governor appointed Fairfax County Circuit Judge Jane Marum Roush, an experienced, consensus jurist. With a Sunday night post, merely two days after the new court member swore her oath of office, Republican General Assembly leaders proclaimed their caucuses' intention to elect another individual, despite conceding that Roush was very qualified. During the August special session, this concerted GOP endeavor prompted a Republican senator to join Democrats who opposed the prospect and concomitantly adjourned. GOP leaders then contended that legislators remained in session, arguing the Virginia Constitution explicitly prescribes that Senate and House of Delegates consent 
to adjourn. The Governor's Counsel next penned an opinion that concluded that lawmakers had adjourned, so McAuliffe could appoint Justice Roush to the court again, a choice that he implemented thirty days after adjournment. Because these efforts precipitated a constitutional standoff and will consequently plague future judicial selection, they warrant analysis.

The initial part of this Article chronicles the rise and evolution of Virginia court selection, detecting that the contemporary system adopted in 1870 performed smoothly for a century. Part Two scrutinizes recent machinations, determining that the procedures now merit improvement. The last section proffers suggestions. For the near term, the Assembly should promptly elect Roush. She brings twenty-two years of laudable judicial service, including over five months as a justice. Moreover, if the partisan machinations that have attended efforts to replace Justice Millette culminate in Roush's removal for reasons bearing no relationship to her abilities, earlier discharge of Roush's judicial responsibilities, or her future capacity to serve, this would make a mockery of the selection regime, undermining citizen respect for it, the Virginia Supreme Court, and the whole state judiciary, as well as the Governor and the Assembly. Across the longer term, the Commonwealth must evaluate and initiate changes that will enhance selection.

\section{A Brief History of Virginia Judicial Selection}

The process's background, which numerous authors have comprehensively assessed, ${ }^{1}$ deserves limited review in this canvass. Over much Virginia history, the state depended on the present regime, ${ }^{2}$ which authorizes legislators to elect new justices unless court vacancies materialize when they are not in session

1. E.g., W. Hamilton Bryson, Judicial Independence in Virginia, $38 \mathrm{U}$. RICH. L. REV. 705 (2004); J. Amy Dillard, Separate and Obedient: The Judicial Qualification Missing from the Job Description, 38 CUMB. L. REV. 1 (2007).

2. VA. Const. art. VI, § 7; see Bryson, supra note 1, at 708-11 (denoting the early history of the judicial selection regime); Dillard, supra note 1, at 4-8 (outlining the recent history of this regime). See generally 2 A.E. Dick HowARD, COMMENTARIES ON THE CONSTITUTION OF VIRGINIA 739-46 (1974) (providing background on this section of the Virginia Constitution). 
or members adjourn yet leave positions empty. ${ }^{3}$ For those circumstances, the Governor appoints the judge who serves until the politicians next come into session when the Assembly can elect this individual or anyone else within thirty days of convening. ${ }^{4}$ That practice requires Governors to select wisely and consult Democratic and GOP lawmakers because they may in fact elect other picks. This idea operated felicitously when a single party controlled the executive and both houses, the norm over the century subsequent to modern procedures' institution. ${ }^{5}$ The scheme has performed less efficaciously since, with growing Republican Party strength and the prevalence of closely divided government. ${ }^{6}$

For the last twenty years, the selection regime deteriorated when relations that involved Democratic and GOP legislators became more contentious. Notwithstanding employment of putative reforms and Democratic Governor Tim Kaine's 2008 success in appointing Justice Millette and naming Justice Bernard Goodwyn-respected, centrist jurists whom the Assembly later elected-the process continued declining. ${ }^{7}$ Therefore, when McAuliffe tendered Roush, the Republicans' decision to install someone else proved unsurprising, although since 1900, lawmakers had elected all thirty-one gubernatorial appointees, including such respected jurists as Harry Carrico, Thomas Gordon, Albertis Harrison, Alexander Harman, George Cochran, Richard Poff, Christian Compton, John Charles Thomas, Elizabeth Lacy, Leroy Hassell, LeRoy Millette, Bernard

3. VA. Const. art. VI, $\S 7$.

4. Id.; see Carl Tobias, Reconsidering Virginia Judicial Selection, 43 U. RICH. L. REV. 37, 39 (2008) (explaining this aspect of Virginia's judicial selection regime).

5. Tobias, supra note 4 , at 41 .

6. One party held the governorship and the other a Senate or House majority. Id. at 41-42.

7. See id. at 42-45 (describing events demonstrating that "the selection process has grown increasingly controversial"); Jeff Schapiro, General Assembly Clears Kaine's Judicial Selections, Rich. Times-Dispatch (Feb. 9, 2008, 7:42 AM), $\quad$ http://www.richmond.com/news/article_19c77fe8-15e4-586a-bb620ac992fcc314.html (reporting that "[t]he General Assembly yesterday endorsed Gov. Timothy M. Kaine's picks for the Virginia Supreme Court and Court of Appeals after Republicans retreated from their threat to throw the two judges off the bench") (on file with the Washington and Lee Law Review). 
Goodwyn, and even Republican Governors' appointees whom a Democratic-controlled Assembly later elected. ${ }^{8}$

\section{Justice Roush's Appointment}

On April 28, 2015, the High Court announced that Justice Millette would retire in ninety days. ${ }^{9}$ The Governor crafted transparent procedures, articulated relevant criteria, and declared that Carlos Hopkins, the Governor's Counsel, would receive expressions of interest until June 15, 2015. ${ }^{10}$ Twelve well-

8. Jim Nolan, Governor Slams GOP Plan to Oust His Pick from Va. Supreme Court, Rich. Times-DisPatch (Aug. 3, 2015, 10:45 PM), http://www.richmond.com/news/virginia/government-politics/article_cfc22cb9-

bd30-5544-9544-99a9ef3babdb.html (on file with the Washington and Lee Law Review); Jenna Portnoy, Va. Republicans to Oust McAuliffe's Supreme Court Pick, Install Their Own, WASH. Post (Aug. 3, 2015), https://www.washingtonpost.com/local/virginia-politics/va-republicans-to-firemcauliffes-supreme-court-pick-install-their-own/2015/08/03/507ff4f2-39e6-11e5b3ac-8a79bc44e5e2_story.html (on file with the Washington and Lee Law Review); Jeff Schapiro, GOP Readying to Dump Roush-Because It Can, RICH. Times-DisPatch, Nov. 15, 2015, at B1. Most notable of the latter is former Chief Justice Cynthia Kinser, whom Republican Governor George Allen appointed, and the Democratic Assembly elected, in 1997. She became Virginia's first female Chief Justice and served with great distinction.

9. Press Release, Supreme Court of Virginia, The Honorable LeRoy F. Millette, Jr., Justice of the Supreme Court of Virginia, Announces Retirement (Apr. 28, 2015) (on file with the Washington and Lee Law Review); see Schapiro, supra note 7 ("Goodwyn and Millette were backed for full terms-12 years and 8 years, respectively-by unanimous votes in the House of Delegates and the Virginia Senate.").

10. See Press Release, Commonwealth of Virginia, Office of the Governor, Governor McAuliffe Announces Process for Replacement of Supreme Court Justice (May 13, 2015) ("Governor McAuliffe today announced the Commonwealth is now taking applications for candidates interested in seeking the seat being vacated by Virginia Supreme Court Justice LeRoy F. Millette, Jr.") (on file with the Washington and Lee Law Review); Tom Jackman, Fairfax Judge Jane Marum Roush Named to Virginia Supreme Court, WASH. Post (July 27, 2015), https://www.washingtonpost.com/local/fairfax-judge-jane-marumroush-named-to-virginia-supreme-court/2015/07/26/e9c18238-324e-11e5-8353-

1215475949f4_story.html ("Millette announced his retirement in April, giving McAuliffe the opportunity to make a recess appointment to the vacancy, rather than allow the General Assembly the opportunity to elect a new justice, a process often criticized for its secrecy and political maneuvering.") (on file with the Washington and Lee Law Review); Peter Vieth, Governor Seeks Applicants for Supreme Court Vacancy, VA. LAWYERS WeEKLY (May 15, 2015), http://valawyersweekly.com/2015/05/15/governor-seeks-applicants-for-supreme- 
qualified judges and lawyers completed applications, while the Counsel and other upper-echelon McAuliffe advisors conducted numerous interviews across July. ${ }^{11}$

The Constitution makes this appointment extremely complex and delicate. It commands the Assembly to elect successors for justices-who retire when the politicians are not in sessionwithin a month of next convening. ${ }^{12}$ This means that the Governor needs to proceed sagely by consulting each party's legislators, as they can select another possibility. McAuliffe did not consult the opposition leadership, ${ }^{13}$ but he relied on support

court-vacancy/ (noting that the governor's office had begun taking applications for candidates and that the deadline to apply was June 15, 2015) (on file with the Washington and Lee Law Review).

11. Paul Fletcher, Seven Seek Seat on High Court, VA. LAWYERS WeEkLY (June 17, 2015), http://valawyersweekly.com/2015/06/17/seven-seek-seat-onhigh-court/; Carl Tobias, And Justices for All, Rich. TIMES-DisPaTch (Aug. 15, 2015, 10:30 PM), http://www.richmond.com/opinion/their-opinion/guestcolumnists/article_3ff199ff-e472-50e0-8867-e5e4c87f642d.html (on file with the Washington and Lee Law Review); see Vieth, supra note 10 (explaining the application process).

12. It can also elect when lawmakers adjourn without filling vacancies to which the Governor appoints judges. That is rarer. See sources cited supra notes 3-4 (explaining Virginia's judicial selection system).

13. See Bill McMorris, Virginia Is for Lovers of Obama-Style Power Plays, WALL ST. J. (Oct. 16, 2015, 6:54 PM), http://www.wsj.com/articles/virginia-is-forlovers-of-obama-style-power-plays-1445036047 ("On Sept. 16, Gov. McAuliffe reappointed Fairfax County jurist Jane Marum Roush to the high court, even though the Republican-controlled House of Delegates, unlike the state Senate, was by its own account still open for business.") (on file with the Washington and Lee Law Review); Jenna Portnoy \& Laura Vozzella, In Decorous Richmond, a Bitter Partisan Battle over a Judicial Post, WAsh. Post (Aug. 17, 2015), https://www.washingtonpost.com/local/virginia-politics/virginia-legislaturereturns-to-richmond-ready-to-rumble/2015/08/16/f6cfea56-447c-11e5-8e7d-

9c033e6745d8_story.html ("Republicans came to town determined to oust Roush-a rare and brazen move against a sitting judge that most of them admitted had little to do with her qualifications. They said they were angry that McAuliffe hadn't consulted them about the selection.") (on file with the Washington and Lee Law Review); Laura Vozzella, McAuliffe's Embattled Supreme Court Pick Makes Debut with Tenure in Doubt, WASH. Post (Sept. 14, 2015), https://www.washingtonpost.com/local/virginia-politics/mcauliffesembattled-supreme-court-pick-makes-debut-with-tenure-in-

doubt/2015/09/14/a946a548-5b0d-11e5-8e9e-dce8a2a2a679_story.html ("The battle over Roush, a highly regarded former Fairfax Circuit Court judge, is the sharpest partisan fight of McAuliffe's tenure. Republicans, who have raised no objections about Roush's qualifications, say the governor mishandled the nomination by not consulting GOP leaders of the House and Senate.") (on file with the Washington and Lee Law Review). 
from Delegate David Albo (R-Fairfax), who chairs the House Courts of Justice Committee, ${ }^{14}$ and a Fairfax County delegation letter, which implored the Governor to propose Roush.

The May 18, 2015 letter on the delegate's stationery lauded the "premiere" Virginia jurist: she is "non-partisan, and most importantly, [knows] that a judge applies, not writes, the law." 15 The Fairfax lawmakers described the candidate as the jurist whom the Court asks to resolve cases arising "elsewhere in the state that the local judges can't handle." ${ }^{16}$ For example, she was the lead jurist in Lee Boyd Malvo's 2003 prosecution and was "handling the Charles Severance triple-murder case."17 The delegation also remarked that geographic diversity was essential because Fairfax County residents are a quarter of Virginians, ${ }^{18}$

14. It reviews candidates. Letter from Del. David Albo et al., to Governor Terry McAuliffe (May 18, 2015) [hereinafter Letter from Del. Albo] (on file with author); see Peter Vieth, Roush Has Backing of Northern Virginia Legislators, VA. LAWYERS WEEKLY (July 26, 2015), http://valawyersweekly.com/2015/07/26/roush-has-backing-of-northern-virginialegislators/ ("On the letterhead of Republican Del. David B. Albo, the mostly Democratic Fairfax delegation described Roush as 'one of the premiere judges in all of Virginia.") (on file with the Washington and Lee Law Review).

15. Letter from Del. Albo, supra note 14; see Jackman, supra note 10 (providing Roush's personal and professional background); Vieth, supra note 14 (detailing Roush's qualifications).

16. Letter from Del. Albo, supra note 14. Illustrative was her three-week trial and comprehensive opinion in the corporate dissolution litigation over kyanite mining in Buckingham County. Jackman, supra note 10; Bill McKelway, Kyanite Mining Case Finally Comes to a Close, Rich. TimesDisPATCH (June 11, 2013, 12:00 AM), http://www.richmond.com/news/stateregional/kyanite-mining-case-finally-comes-to-a-close/article_6ba375d3-aebb5a42-995e-7c5fdc7d076d.html (on file with the Washington and Lee Law Review).

17. Letter from Del. Albo, supra note 14; see Tom Jackman, Judge Rejects Bid to Delay Malvo Trial; Fairfax Prosecutors Sought More Time for Mental Health Evaluation, WASH. PosT, Oct. 24, 2003, at B1 (describing Roush's ruling); Matt Zapotosky, Charles Severance, Accused in 3 Alexandria Killings, Interrupts His Own Defense, WASH. PosT (Dec. 11, 2014), https:/www.washingtonpost.com/local/crime/charles-severance-accused-of-threealexandria-killings-to-appear-in-court/2014/12/10/971a1c52-80a1-11e4-9f3895a187e4c1f7_story.html (outlining developments in the Severance case) (on file with the Washington and Lee Law Review).

18. Letter from Del. Albo, supra note 14; see Vieth, supra note 14 (stating that the legislators wrote, "Fairfax County holds $25 \%$ of the state's population, but we have not had a Fairfax judge appointed to a seat on the Supreme Court for many years"). 
observing that Barbara Keenan, the last justice from this area, captured initial election during $1991 .{ }^{19}$

On July 27, 2015, McAuliffe appointed Roush. ${ }^{20}$ Despite her impeccable credentials, within forty-eight hours of Roush assuming her post, GOP leaders determined they would choose someone else. On Sunday night, August 2, 2015 House Speaker William Howell (Stafford) and Senate Majority Leader Thomas Norment (James City) "announced that [both] caucuses" planned on supporting Judge Rossie D. Alston, Jr., a court of appeals member. ${ }^{21}$ Norment correspondingly acknowledged that McAuliffe had named a "different candidate, who is also highly qualified," yet clearly expected that legislators would instead elect their prospect in the upcoming session. ${ }^{22}$

19. Letter from Del. Albo, supra note 14; see McMorris, supra note 13 ("She hails from Fairfax County in the reliably Democratic Washington, D.C. suburbs and is the first Northern Virginia nominee in more than a decade.").

20. Press Release, Commonwealth of Virginia, Office of the Governor, Governor McAuliffe Names Judge Jane Marum Roush as Next Justice of the Supreme Court of Virginia (July 27, 2015); see Andrew Cain, McAuliffe to Name Roush to State Supreme Court, Rich. Times-DisPatch (July 24, 2015, 8:27 PM), http://www.roanoke.com/news/virginia/mcauliffe-to-name-roush-to-statesupreme-court/article_13337516-d480-5d32-b3e6-a14aba7a8777.html (announcing the Governor's plans to appoint Roush) (on file with the Washington and Lee Law Review); Jackman, supra note 10 (same).

21. Speaker Howell \& Leader Norment on the Virginia Supreme Court Vacancy, DELEGATE BILL Howell (Aug. 2, 2015), https://www.williamjhowell.org/speaker-howell-leader-norment-on-the-virginiasupreme-court-vacancy/; Jim Nolan, In Surprise Move, Senate Democrats Adjourn Special Session, Rich. Times-DisPATch (Aug. 17, 2015, 9:30 PM), http://www.richmond.com/news/virginia/government-politics/article_7b98d1054949-502d-ba7a-435380baee58.html (on file with the Washington and Lee Law Review); Alicia Petska, Supreme Court Appointment Conflict Comes to a Head Monday, RoANOKE TIMES (Aug. 14, 2015, 5:44 PM), http://www.roanoke.com/news/local/supreme-court-appointment-conflict-comesto-a-head-monday/article_ea859e4a-bdc9-59fd-a7c3-335eb9439281.html (on file with the Washington and Lee Law Review); see supra note 13 (describing how the Governor did not consult with Republican leaders before deciding to appoint Roush).

22. Howell, supra note 21; Nolan, supra note 8; see supra note 13 (describing the partisan conflict in greater detail). It bears emphasis that the GOP leaders were concerned about McAuliffe's failure to consult directly with them before appointing Roush, not about her abilities. Indeed, Howell recently stated: "In August, despite our preference to elect Judge Alston, House leaders and I acknowledged Justice Roush was a qualified candidate." Laura Vozzella, McAuliffe Suggests He Was Victim of Republican 'Set-Up' in Judicial Battle, WASH. Post (Dec. 9, 2015), https://www.washingtonpost.com/local/virginia- 
On August 7, 2015, Senate Minority Leader Richard Saslaw (Fairfax) and House Minority Leader David Toscano (Charlottesville) respectfully asked the Courts of Justice Committees' leadership to duly "consider the respective qualifications of Justice Roush" and the GOP pick; they directly stated the "Constitution makes very plain" that the General Assembly, not the Republican caucuses, has the duty for selecting jurists. ${ }^{23}$ Howell peremptorily responded: "We've made the decision to elect" Alston, so interviewing Roush proved unnecessary. ${ }^{24}$ Senate GOP Caucus Chair Ryan McDougle (Hanover) anticipated their choice's "election [the] next week"; he posited that suggesting interviews for other designees "is merely political theater." 25

On August 17, 2015, Republican election of candidate Alston in turn failed when one prominent, centrist, GOP senator and Democrats eschewed this possibility and concomitantly adjourned. ${ }^{26}$ When Republicans urged that the Constitution's

politics/mcauliffe-suggests-he-was-victim-of-republican-set-up-in-judicialbattle/2015/12/09/b050b1f6-9e99-11e5-a3c5-c77f2cc5a43c_story.html (on file with the Washington and Lee Law Review).

23. Letter from Sen. Richard Saslaw \& Del. David Toscano to Sens. Tommy Norment \& Mark Obenshain, Dels. David Albo \& Rob Bell (Aug. 7, 2015) (on file with author); see Jenna Portnoy, Battle Over Va. Justice Heats up as Democrats Demand Hearings, WASH. PosT (Aug. 10, 2015), https://www.washingtonpost.com/local/virginia-politics/battle-over-va-justiceheats-up-as-democrats-demand-hearings/2015/08/10/7c776036-3f9a-11e5-95614b3dc93e3b9a_story.html (reporting that "Democratic leaders called on Republicans who control the General Assembly to hold public hearings to consider McAuliffe's pick as well as their own for the next justice of the state's highest court") (on file with the Washington and Lee Law Review).

24. Portnoy, supra note 23; see Nolan, supra note 21 ("[T] committee that nominated Alston for the job denied Roush an interview to discuss her seat on the court.").

25. Portnoy, supra note 23; see Petska, supra note 21 ("Alston is the only Supreme Court candidate set to be interviewed when the legislature reconvenes for a special session Monday.").

26. Sen. John Watkins (Powhatan) deemed the process flawed and in need of repair. See Nolan, supra note 21 ("Watkins, a moderate Republican, had indicated he was concerned over the precedent of allowing politics to directly influence the firing of a sitting Supreme Court justice who otherwise is highly qualified for the job."); Jenna Portnoy, Va. Democrats Revive Roush Judgeship, WASH. Post (Aug. 17, 2015), https://www.washingtonpost.com/local/virginiapolitics/va-democrats-revive-roush-judgeship/2015/08/17/0555b808-4518-11e58e7d-9c033e6745d8_story.html (describing how Senate Democrats kept Roush's "appointment alive with a parliamentary maneuver") (on file with the 
phraseology dictated that lawmakers actually remained in session, ${ }^{27}$ the Governor's Counsel authored a cogent opinion that explicitly determined that the legislature had indeed adjourned. ${ }^{28}$ Thus, McAuliffe could proffer Roush again, a choice which he effectuated on September 15, 2015. ${ }^{29}$ The GOP leaders vigorously argued that both houses need to consent for adjournment, challenging the legitimacy of decisions in which Roush might

Washington and Lee Law Review); supra note 13 (outlining the challenge to Roush's appointment).

27. Statement of Speaker Howell \& Majority Leader Norment on Fourth Day of Unconstitutional Action by Senate, Delegate Bill Howell (Aug. 21, 2015), https:/www.williamjhowell.org/statement-by-speaker-howell-andmajority-leader-norment-on-fourth-day-of-unconstitutional-action-by-senate/; see Jim Nolan \& Andrew Cain, GOP Leaders Insist the General Assembly Still Is in Session, Rich. Times-DisPatch (Aug. 18, 2015, 12:54 PM), http://www.richmond.com/news/virginia/government-politics/article_e01188b886b6-54be-9ddd-9d917e7a98ed.html (describing the Republican leaders' argument) (on file with the Washington and Lee Law Review); Jenna Portnoy, Republicans Escalate Fight with McAuliffe over Supreme Court Judge, WASH. Post (Aug. 19, 2015), https://www.washingtonpost.com/local/virginiapolitics/republicans-escalate-fight-with-mcauliffe-over-supreme-court-

judge/2015/08/19/71309724-466b-11e5-8ab4-c73967a143d3_story.html ("At issue is a procedural question about whether Monday's special session was properly adjourned. When the legislature is not in session, McAuliffe may appoint a judge on an interim basis ....") (on file with the Washington and Lee Law Review).

28. Letter from Carlos Hopkins, Counsel to the Governor, to Hon. William Howell \& Hon. Thomas Norment (Sept. 15, 2015) [hereinafter Letter from Hopkins], http://governor.virginia.gov/media/4592/draft-letter-to-speaker-finaldraft-9-15-15-130pm.pdf; see Laura Vozzella, McAuliffe Asserts Legal Right to Reappoint Supreme Court Justice, WASH. Post (Sept. 15, 2015), https://www.washingtonpost.com/local/virginia-politics/mcauliffe-asserts-legalright-to-reappoint-supreme-court-justice/2015/09/15/23139820-5bdd-11e5-b38e06883aacba64_story.html (describing the letter that the Governor's Counsel drafted and Howell's and Norment's reactions to that letter) (on file with the Washington and Lee Law Review).

29. Press Release, Commonwealth of Virginia, Office of the Governor, Governor McAuliffe's Statement on Reappointment of Justice Jane Marum Roush (Sept. 15, 2015) (on file with the Washington and Lee Law Review); see Andrew Cain, McAuliffe to Reappoint Roush to Va. Supreme Court Today, RICH. Times-DisPatch (Sept. $\quad 15, \quad 2015, \quad 3: 36 \quad$ PM), http://www.richmond.com/news/virginia/government-politics/article_e8917e8f7bb8-5435-93ec-996286dde6a0.html (reporting Governor McAuliffe's decision to appoint Roush again) (on file with the Washington and Lee Law Review); Vozzella, supra note 13 (noting that "McAuliffe has vowed to reappoint Roush on Thursday, but Republicans say he lacks the authority to do so"); Vozzella, supra note 28 (describing the Governor's stance, as outlined in his letter to Howell and Norment). 
participate. $^{30}$ Some partisan sniping over her reappointment between the Governor and GOP leadership continued during the autumn and may have peaked in December when McAuliffe intimated that the controversy about Roush was a Republican setup to which Howell responded: "Justice Roush disqualified herself from service on the court when she accepted an unconstitutional appointment from the Governor." 31

Hopkins's deft evaluation is the better reading. He ascertained that the Constitution's essential structural design restricts lawmaking power by supplying a part-time citizen Assembly, while two ideas that emanate from this structure prompted the conclusion that legislators were not in session: (1) the August upper chamber adjournment sine die, and (2) the lack of "continuous or even pending" action in the Senate or House. ${ }^{32}$ Regarding the first point, the Counsel undertook

30. Speaker Howell \& Leader Norment on Governor McAuliffe's Decision to Reappoint Justice Roush to the Supreme Court, Delegate Bill Howell (Sept. 15, 2015), https://www.williamjhowell.org/speaker-howell-leader-norment-ongovernor-mcauliffes-decision-to-reappoint-justice-roush-to-the-supreme-court/ (on file with the Washington and Lee Law Review); see Schapiro, supra note 8 ("Republicans contend-and this is a murky constitutional issue subject to conflicting, if not partisan, interpretation-that Roush was improperly appointed by McAuliffe. Because, Republicans say, the legislature technically was still in session, the governor had no authority to name her."); Vozzella, supra note 13 (reporting the debate over whether the Governor procedurally had to consult with GOP leaders before deciding to appoint Roush); Laura Vozzella \& Jenna Portnoy, As Time Runs Out on McAuliffe's Pick, Va. Supreme Court Shuffles Docket, WAsh. Post (Aug. 31, 2015), https://www.washingtonpost.com/local/virginia-politics/as-time-runs-out-onmcauliffe-pick-vas-high-court-shuffles-docket/2015/08/31/91a17506-4f89-11e58c19-0b6825aa4a3a_story.html ("Virginia's highest court will cram four days of oral arguments into three, allowing it to wrap up its September session before time runs out on Gov. Terry McAuliffe's embattled Supreme Court pick.") (on file with the Washington and Lee Law Review); Supreme Court of Virginia Opinions, VIRGINIA's JUDICIAL SYSTEM, http://www.courts.state.va.us/scndex.htm (showing Roush's participation in thirteen opinions and authorship of one opinion) (on file with the Washington and Lee Law Review).

31. Howell added: "By not being interviewed, Justice Roush cannot be certified. Because she will not be certified, she will not be eligible for election." Vozzella, supra note 22; Graham Moomaw, McAuliffe Suggests Republican 'SetUp' in Flap Over Supreme Court Pick, RICH. Times-DisPatch (Dec. 9, 2015, 10:30 PM), http://www.richmond.com/news/virginia/governmentpolitics/article_ebdd75e2-bc1d-50a1-9882-8e6910f71a0a.html (on file with the Washington and Lee Law Review).

32. Letter from Hopkins, supra note 28, at 1-2 (citing VA. ConsT. art IV, $\S 6 ; 1$ HowARD, supra note 2 , at 491-92). 
exacting legal analysis of the Constitution's words. Hopkins asserted that the consent mandate's distinct inclusion in the article six paragraph covering only regular sessions and exclusion from the next paragraph governing merely special sessions demonstrate that consent is required to adjourn the former kind but not the latter. ${ }^{33}$ As to the other proposition, the Counsel deemed the absence of some "continuous or even pending" activity in the two bodies correspondingly favored adjournment. ${ }^{34}$ Because the specific purpose for calling the session had already ended, it was plainly over, a conclusion that members' behavior reaffirmed. ${ }^{35}$ For example, after the upper chamber instigated adjournment, every senator who protested nonetheless clearly adjourned, delegates left the Capitol, and the houses managed to conduct no official action. ${ }^{36}$

In sum, Roush was the first gubernatorial court appointee whom lawmakers failed to elect in 115 years; the executive and legislature could have avoided this misstep, however, if each communicated appropriately. During the 2016 legislative session, Republican lawmakers are poised to remove a highly experienced justice whom the Governor has appointed, depriving Virginia of her substantial expertise derived from more than two decades of public service. More importantly, removal of a sitting Justice from the court for political reasons-reasons unrelated to her qualifications, past performance, or future ability to serve-would undercut public regard for the Virginia Supreme Court and Virginia's entire state court system as well as the executive and legislative branches. The counterproductive dynamic that troubled Justice Roush's process illustrates that the system does not operate efficaciously, perhaps replicating the downward spiral of corrosive phenomena that undercut the federal regime. ${ }^{37}$

33. Id. (citing VA. Const. art. IV, § 6; Nat'l Fed'n of Indep. Bus. v. Sebelius, 132 S. Ct. 2566, 2577 (2012)). Without an express constitutional proscription on the clear Senate interpretation that it had authority to adjourn sine die, deference must be accorded this construction and, thus, the Assembly properly adjourned. $I d$. at 4 .

34. Id. at $4-5$.

35. Id.

36. Id. at 5. For a different view, see McMorris, supra note 13.

37. See Graham Moomaw, 24 Past Virginia Bar Presidents Criticize Dustup over Supreme Court Appointment, RICH. Times-DisPatch (Aug. 13, 2015, 2:45 $\mathrm{PM}), \quad$ http://www.roanoke.com/news/politics/past-virginia-bar-presidents- 
Accordingly, the concluding part examines short- and long-term concrete proposals, which the Governor and lawmakers should consider and implement.

\section{Suggestions for the Future}

\section{A. Short-Term Suggestions}

When members assemble on January 13, 2016, they promptly ought to elect Justice Roush, who is a highly experienced jurist with much support in the courts, legislature, bar, and public. Her expert, nuanced disposition of myriad intractable cases shows that Roush possesses the attributes to be a superb justice: wisdom, diligence, ethics, independence, and balanced judicial temperament. ${ }^{38}$ Nevertheless, today's exceedingly partisan milieu inspires little confidence that the jurist will attain election. ${ }^{39}$

criticize-dustup-over-supreme-court-appointment/article_e08fd655-4eca-5ed38b51-5e16b826b2a6.html (reporting that "[t]wo dozen former presidents of the Virginia Bar Association have sent a letter to state leaders criticizing the political feuding over appointments to the state Supreme Court, saying that the removal of a sitting justice would "make a mockery of the Virginia judicial appointment process"') (on file with the Washington and Lee Law Review). See generally Carl Tobias, Senate Gridlock and Federal Judicial Selection, 88 NoTRE DAME L. REV. 2233 (2013) (outlining the conundrum that is federal judicial selection, caused by "rampant partisanship and skyrocketing caseloads, which necessitate more judicial positions").

38. See supra notes 15-17 and accompanying text (describing Roush's background and qualifications more extensively).

39. See Schapiro, supra note 8, at B1 ("Now, Roush could lose her job after six months. Republicans can largely ignore Democrats. And McAuliffe, who selected Roush for the state's highest court in July, could be reduced to an ineffective afterthought by a Republican majority whose conservative base expects it to do just that."); Jeff Schapiro, GOP Holds Senate, Thwarting McAuliffe at Crucial Point in Term, Rich. Times-DisPatch (Nov. 3, 2015, 8:59 $\mathrm{PM}$ ), $\quad$ http://www.richmond.com/news/virginia/governmentpolitics/article_1262cb75-ad82-5cb2-aea3-393c4e97ffec.html (describing the "Republican hostility for McAuliffe") (on file with the Washington and Lee Law Review); Editorial, Our View: 11 Thoughts on the Election, RoAnOKE Times (Nov. 5, 2015, 2:15 AM), http://www.roanoke.com/opinion/editorials/our-viewthoughts-on-the-election/article_3744d6b2-b7a0-500d-84a3-4676d0897cbe.html (predicting that "Supreme Court Justice Jane Roush probably needs to look for work") (on file with the Washington and Lee Law Review); supra note 31 and accompanying text. 


\section{B. Longer-Term Suggestions}

In contemplating future appointments to the court, the Governor should assiduously consult both Assembly parties, especially the leadership, while specific lawmakers need to be receptive and cooperative when denominating impressive people. ${ }^{40}$ The executive and legislators should also meticulously canvass and use practices that have improved selection elsewhere. ${ }^{41}$ One constructive idea, which the Governor and lawmakers can now explore and prescribe, is merit selection commissions that would resemble the diverse panels that many states apply. They could advise the executive and legislature by, for instance, cautiously recommending accomplished, mainstream prospects. ${ }^{42}$ A statute can detail numerous parameters, encompassing membership and operational rules, notably if lawmakers would serve, exactly how many names a commission will forward and whether the Governor or Assembly must designate one. ${ }^{43}$

Permanent, rather dramatic, structural reforms deserve consideration and potential institution, but some remedies would necessitate constitutional amendment. For example, Virginia might design a regime premised on the federal construct that

40. See supra notes 7, 13-14 and accompanying text (explaining how the Governor failed to consult with Republican leaders before appointing Roush, who was nonetheless a well-qualified applicant, and how this latest conundrum exemplifies the downward spiral of the judicial selection process in Virginia).

41. See Tobias, supra note 4 , at $47 \&$ n.47 (describing alternative methods of judicial selection that have worked in other jurisdictions, such as gubernatorial nomination and popular election).

42. See id. at 45-46 ("One measure that the Old Dominion could adopt in the near term is a merit selection commission that would recommend multiple, excellent candidates whom the General Assembly in turn could elect."). State bar group vetting of candidates has proved useful, but panels merit formalization. See CoMm'N ON INTEGRITY \& PUB. Confidence In STATE Gov'T, Final Report of the Commission on InTEGRITy AND Public Confidence IN $\begin{array}{lll}\text { STATE GOVERNMENT } & \text { 25-26 }\end{array}$ https://governor.virginia.gov/media/5103/integrity-commission-final-report-dec2015.pdf.

43. See Mark Behrens \& Cary Silverman, The Case for Adopting Appointive Judicial Selection Systems for State Court Judges, 11 CoRnELl J. L. \& Pub. POL'Y 273, 302 (2002) (listing factors that states seeking to adopt a merit judicial selection system should consider); supra note 42 (providing various methods of judicial selection that states and the federal system employ). 
deploys gubernatorial nomination with legislative advice and consent, yet mounting gridlock has recently infected the national approach. ${ }^{44}$ This solution would eclipse Virginia's present system, however, because it can enlarge merit and judicial independence.

Were the Governor or Assembly to doubt the promise of the suggestions proffered, both could review and effectuate one venerable notion: a study commission that would assess pressing selection complications and develop proposals for improvement. ${ }^{45}$ The Governor's Ethics Commission in turn has been scrutinizing Virginia's procedures, and even though other concerns seemingly assumed higher priority, its endeavors should prove instructive. ${ }^{46}$

\section{Conclusion}

When lawmakers convene, they ought to elect Justice Roush because she possesses over twenty-two years of highly pertinent judicial experience and because her removal for reasons that are not related to her capabilities will erode citizen respect for the selection process, as well as all three coequal government branches. The Governor and legislature should also

44. Tobias, supra note 4, at 47; see 161 ConG. REC. S7963 (daily ed. Nov. $16,2015)$ (statement of Sen. Leahy) ("In the 11 months that the Senate has been under Republican control this year, the Senate has only voted to confirm nine judges. This obstruction has resulted in needless delays for hardworking Americans who seek justice in our Federal courts. . . It does not have to be this way."). See generally Tobias, supra note 37 (providing an overview of the federal selection gridlock).

45. VA. House of Delegates R. 20 (2015); VA. Senate R. 19(a), (h) (2015); see Tobias, supra note 4, at 48 (suggesting that "the Assembly may want to invoke the venerable study commission process, which legislators have long employed to analyze a number of particularly difficult complications and formulate efficacious solutions").

46. E.g., Comm'n on Integrity \& Pub. Confidence In State Gov't, supra note 42; DAVID Jonas, Good Governance AND ETHICs ReForm: Best PRACTICES AND POLICY RECOMMENDATIONS 11 (2014), https://governor.virginia.gov/media/3238/ethics-package-best-practices-updated9_24_14.pdf; see Graham Moomaw, State Ethics Commission Recommends $\$ 15,000$ Pay Raise for Legislators, Rich. Times-DisPatch (Oct. 19, 2015, 9:45 PM), $\quad$ http://www.richmond.com/news/virginia/governmentpolitics/article_7d4ffbba-f575-5fb6-90ea-f75c64c4cf69.html (listing "[d]eveloping a uniform evaluation system for judicial candidates at all levels" as an additional recommendation of the Commission) (on file with the Washington and Lee Law Review). 
collaboratively identify practices that will distinctly enhance the system, as the process for replacing Justice Millette was not satisfactory. 